\title{
Desafios do reconhecimento nas relações íntimas: um debate com Axel Honneth
}

Patrícia Mattos'

\section{Resumo}

Em diálogo com Axel Honneth, analiso os desafios do reconhecimento nas relações íntimas à luz de pesquisas qualitativas realizadas com homens e mulheres heterossexuais de classes média e média alta sobre o amor romântico nos dias de hoje. As pesquisas revelaram as ambiguidades que resultaram do crescente processo de individualização e democratização das relações de gênero na intimidade. Ainda que o reconhecimento nas relações íntimas seja importante para homens e mulheres, estas explicitaram, de forma mais enfática, o déficit de reconhecimento nessas relações - não reconhecimento, reconhecimento precário ou falso. Destaco as formas de sofrimento emocional feminino criadas com a institucionalização do campo sexual, que separou sexo de envolvimento afetivo, apontando os dilemas e as contradições da liberdade sexual para as mulheres. $\mathrm{Se}$, por um lado, a reconstrução normativa das relações íntimas de Honneth consegue elucidar as regras morais tacitamente postas nas interações amorosas e a importância do amor para uma teoria moral da "boa vida", por outro, superestima as potencialidades do reconhecimento na esfera íntima. Além disso, pretendo mostrar as ambivalências do "novo feminismo" e as limitações dos estudos de gênero e sexualidade contemporâneos, com ênfase nas sexualidades "não normativas" e na desconstrução dos binarismos de gênero que, contraditoriamente, contribuem para eclipsar diferenças de gênero em torno do amor e da sexualidade, e, com isso, acabam colaborando para tornar imperceptiveis sofrimentos femininos.

Palauras-chave: Amor. Reconhecimento. Ambiguidade. Liberdade Sexual. Feminismo.

Professora do Departamento de Ciências Sociais da Universidade Federal de São João del-Rei (UFSJ).

* Agradeço a Rosinha Carrion, Ricardo Visser e Teresa Santa Cruz pelos comentários e pelas críticas à primeira versão deste texto. atribua a autoria da obra, forneça um link para a licença, e indicar se foram feitas alterações. 


\section{Introdução}

O debate com Nancy Fraser (FRASER; HONNETH, 2003) levou Axel Honneth a repensar, desenvolver e rever algumas premissas sobre as quais embasou originalmente sua teoria do reconhecimento. Honneth percebeu que, na esfera do amor, sua análise foi mais antropológica, dando a entender que essa dimensão seria a menos sujeita à mudança (MARCELO, 2013 , p. 211). Ficou mais claro para Honneth que os padróes de reconhecimento nas relações íntimas podem mudar e progredir tanto em função da dinâmica interna de institucionalização do princípio do amor - que presume que as pessoas devam incorporar as implicaçóes normativas desse princípio, abrindo inclusive espaço para novas reivindicaçóes que podem ampliar as relaçóes de reconhecimento na intimidade - como também por influência de outra esfera, como foi o caso das leis que penalizam o estupro dentro do casamento ou a violência doméstica (MARCELO, 2013, p. 211-212).

Em seu livro $O$ direito da liberdade $e^{2}$. Honneth (2015) procura superar o "mal-entendido antropológico" (MARCELO, 2013, p. 210). Para isso, historiciza e analisa as especificidades das formas de reconhecimento na esfera das relaçóes pessoais (de amizade, íntima e familiar). Contudo, afirma não abandonar a intuição antropológica "[...] de que os seres humanos dependem de formas sociais de reconhecimento para desenvolver uma identidade e para ganhar um certo entendimento e uma suficiente forma de autorrelação "” (MARCELO, 2013, p. 210). Seu interesse se volta para fazer uma reconstrução histórico-normativa da nova concepção de amor criada pelo romantismo, que coloca o amor como um fim em si mesmo, livre de

2 Com o método de reconstrução histórico-normativa das três esferas de ação - das relações pessoais (de amizade, intimas e familiares), das interações na economia de mercado e da vida politica, Honneth afirma que a liberdade pensada como autonomia individual é o valor central das sociedades liberal-democráticas. Honneth se preocupa em reconstruir "[...] as práticas constitutivas e negligenciadas de reconhecimento mútuo e obrigações de papéis complementares" entre os atores sociais nas três esferas (MCNAY, 2015, p. 173). Identificar as anomias e patologias sociais que comprometem nessas esferas a liberdade social, que significa fazer dos interesses e necessidades do outro condição da própria liberdade, é a proposta de Honneth para reavivar a práxis ética. Sobre as críticas feitas à reconstrução normativa, consultar os artigos de Jörg Schaub, Fabian Freyenhagen, Timo Jütten, David McNeill e Lois McNay, publicados em Critical Horizons, v. I6, n. 2 , 2015. Sobre esse debate no Brasil, ver dossiê "Justiça e instituições sociais na democracia", organizado por Cinara L. Rosenfield e Emil Sobottka (2015).

3 Esta e todas as citações em inglês foram traduzidas liuremente por mim. 
coerções e interesses externos. Nas interações íntimas, Honneth delineou o caminho de desenvolvimento das relaçôes de reconhecimento recíproco entre os amantes, demonstrando que somente a partir da revolução sexual essa concepção de amor, voltada essencialmente para o sentimento e o desejo sexual dos amantes, foi sendo institucionalizada nas práticas sociais de homens e mulheres em geral.

Honneth considera as relaçóes sociais afetivas como modelo normativo, como o "epítome das virtudes democráticas" (McNAY, 2015, p. 173).

[...] uma vez que todas as relações baseadas no amor e no cuidar podem ser entendidas, desde o início da modernidade, como relações baseadas na ideia normativa de que os indivíduos se completam reciprocamente para permitir em conjunto a sua própria autorrealização e, por conseguinte, uma pessoa deveria representar uma condição de liberdade para as outras. (HONNETH, 2017, p. 117-118).

Em artigo anterior (MATTOS, 2016), estabeleci um debate crítico entre Honneth e Eva Illouz para discutir os paradoxos da transformação da intimidade, salientando a necessidade de pesquisas empíricas para averiguação das potencialidades e limitaçóes do reconhecimento nas relaçóes íntimas. Dando continuidade ao esforço de refletir criticamente sobre essa questão, concentro-me neste artigo na discussão sobre o tema das relaçôes amorosas no Brasil. Os estudos sobre gênero e sexualidade no Brasil têm se concentrado, notadamente, em sexualidades "não convencionais", "não normativas" e "não hegemônicas" (SIMÔES; CARRARA, 2014, p. 77), em consonância com as lutas feministas e de minorias sexuais pela desconstrução dos binarismos de gênero. O chamado "novo feminismo" é marcado pela militância jovem e pela diversidade de mulheres - negras, lésbicas, transexuais, dentre outras. Mesmo sendo fragmentado, polifônico e permeado de tensôes, o ideário do "novo feminismo" radicaliza a crítica ao binarismo de gênero (HEILBORN; O’DWYER; RIBEIRO, 2018, p. 89). Essa ideia de desconstrução vem sendo colocada como um ideal normativo ${ }^{4}$. Mais à frente, comentarei sobre os problemas dessa nova normatividade. Tenho observado que, no campo de estudos de gênero, as pesquisas

4 Cf. dossiê da revista Cult " $A$ quarta onda", publicado em 2016, com o título: "A revolução será feminista, negra, jovem, vadia, queer, ou não será”. 
sobre sexualidade e amor heterossexuais vêm sendo relegadas para segundo plano ${ }^{5}$. Há certa carência de pesquisas atuais sobre amor e sexualidade heterossexuais nas ciências sociais entre nós, o que tem motivado as pesquisas ${ }^{6}$ que venho desenvolvendo nos últimos anos sobre o tema.

A proposta deste artigo é apresentar os resultados dessas pesquisas, discutindo os desafios do reconhecimento nas relaçôes íntimas. Foram feitas pesquisas qualitativas com homens e mulheres heterossexuais de classes média e média alta no Rio de Janeiro, Brasília, Juiz de Fora e São João del-Rei, tendo sido a maioria das entrevistas realizadas no Rio de Janeiro. Inspirada nos trabalhos de Honneth (2015) e Illouz (1997, 2011, 2012), interessei-me por investigar as especificidades do amor romântico nos dias de hoje e os dramas em torno do amor, isto é, sonhos, realizaçôes, expectativas, frustrações e sofrimentos emocionais vividos por homens e mulheres para saber como se reestruturam as relaçóes de gênero na esfera íntima em face da crescente emancipação feminina. Minha intenção foi investigar o sentido do amor romântico para os entrevistados e as entrevistadas, visando a verificar se há diferenças entre homens e mulheres no que diz respeito ao papel do amor em suas vidas e à importância do reconhecimento no amor. Como estudos (ILLOUZ, 1997; ABOIM, 2006, 2009; MATTOS, 2006, 2009; SILVA; TORRES; BERG, 2009) têm mostrado as diferenças entre as classes nas interaçóes amorosas, sendo os casais de classes média e alta mais propensos que os de classe baixa a estabelecerem relaçóes íntimas baseadas na autonomia e autorrealização dos amantes, meu foco também foi averiguar até que ponto se concretizam nas práticas amorosas dos casais de classes média e média alta as condiçôes de reconhecimento mútuo entre os amantes para a efetiva realização desses ideais. Mesmo que o amor tenha um papel importante na vida

5 Há pesquisadores(as) que veem os estudos sobre amor heterossexual sempre podendo reafirmar a heteronormatividade. Inclusive, o(a) parecerista de um dos meus projetos, apesar de reconhecer o "potencial inovador da proposta", destacou que o "recorte empírico do projeto em homens e mulheres deixou de problematizar o heterossexismo dos estudos sobre amor".

6 Desde 2014, venho realizando pesquisas sobre o amor romântico. Na primeira pesquisa, intitulada "Os fios que ligam sentimento e capitalismo na esfera intima", financiada pelo Conselho Nacional de Desenvolvimento Científico e Tecnológico (CNPq), meu objetivo era discutir as interfaces e tensões entre amor e capitalismo. Ao fazer as entrevistas, mais do que a vivência do romance e de consumos de rituais românticos, deparei-me com sofrimentos emocionais e frustrações de expectativas amorosas, o que me fez mudar o foco de análise e me aprofundar nessa questão na pesquisa de pós-doutorado, denominada "As relações de gênero em torno do amor", desenvolvida na PUC-Rio. 
de homens e mulheres entrevistados, o déficit em torno do reconhecimento nos relacionamentos afetivo-sexuais - não reconhecimento, reconhecimento precário ou falso ${ }^{7}$ - ficou mais explícito na fala das mulheres. Foi possível perceber dilemas e contradiçóes da liberdade sexual para as mulheres e as limitaçôes do feminismo e dos estudos de gênero no Brasil para tematizar essas questóes. Para desenvolver meu argumento, inicialmente, apresento a discussão feita por Honneth sobre a interdependência entre reconhecimento e liberdade na esfera íntima, recuperando os pontos centrais de sua reconstrução histórico-normativa; em seguida, examino as limitaçóes dessa reconstrução e, por fim, analiso os achados das pesquisas.

\section{A interdependência entre liberdade e reconhecimento na esfera íntima}

Enquanto algumas feministas da segunda onda ${ }^{8}$ percebiam a idealização romântica como um instrumento de dominação masculina, Honneth destaca seu potencial emancipatório para concretização de relaçóes mais igualitárias entre os gêneros na esfera íntima.

7 O reconhecimento pleno nas interações afetivas constitui o núcleo da idealização romântica, sendo sua realização na prática dos casais, em alguma medida, sempre mais limitada devido ao contexto histórico e às estruturas de poder. No debate com Fraser (FRASER; HONNETH, 2003). Honneth corrige sua tese de que a esfera do amor tem um potencial normativo a-histórico e, em $\mathrm{O}$ direito da liberdade, argumenta que o ideal romântico descrito por Hegel não estava institucionalizado no casamento, "[...] já que as mulheres, em razão das atribuições de papéis que então imperavam, dispunham de reduzidas possibilidades para articular suas necessidades de maneira livre e sem coerção (HONNETH, 2015, p. 259-260). Em Luta por reconhecimento, Honneth percebe "[...] o reconhecimento como um processo ininterrupto de confirmação e reconfirmação da valorização positiva dos indivíduos nas diversas esferas de ação social" (MATTOS, 2016, p. 434). Na esfera do amor, ser reconhecido(a) permite aos indivíduos desenvolver a confiança para levar a cabo seus projetos de autorrealização, abrindo espaço para que os indivíduos possam articular novas dimensões da sua subjetividade que, possivelmente, reivindicarão novas formas de reconhecimento. O não reconhecimento é visto como a negação ou a frustração da expectativa de ser reconhecido(a). Já o reconhecimento precário é entendido como formas parciais e insuficientes de reconhecimento, enquanto o falso é a expressão da contradição entre a promessa de reconhecimento dada ao sujeito e sua realização na prática.

8 Eva Illouz critica as feministas da segunda onda - Catharine MacKinnon, Ti-Grace Atkinson, Shulamith Firestone, entre outras - por terem atrelado o amor à dominação patriarcal, não conseguindo perceber a importância que o amor tem também para os homens. A autora fala sobre o equívoco das feministas de associarem o amor ao patriarcado, pois, sob a égide do patriarcado, "[...] o amor cumpria um papel muito menos significativo na subjetividade dos homens e das mulheres". Além do mais, assim como Honneth, Illouz vê o amor como estando "[...] vinculado a uma diminuição do poder masculino dentro da família e com o aumento da igualdade e da simetria das relações de gênero" (ILLOUZ, 20I2, p. 5). 
Só com o movimento romântico que surgiu essa ideia. Antes havia outros conceitos de amor e relações pessoais e íntimas, mas só com a institucionalização da ideia de amor essa forma específica se desenvolveu. E esse desenvolvimento se deu a partir de lutas por reconhecimento, no sentido de lutas sobre como entender as implicações do que significa amar alguém. (MARCELO, 2013, p. 211).

Assim como Elias (1994), Beck e Beck-Gernsheim (2017) e Giddens (1993), Honneth também vê o amor como "um dos pilares da individualização”, para usar a expressão de Aboim (2009, p. 108). Individualização significa que "[...] a biografia das pessoas se desvincula dos modelos e certezas tradicionais, de controles alheios e das leis morais suprarregionais e é posta na ação de cada indivíduo, de modo aberto, dependente de decisóes e como uma tarefa" (BECK; BECK-GERNSHEIM, 2017, p. 17). As relaçóes íntimas baseadas no amor, livres de coerçôes externas e interesses instrumentais, tornaram-se uma realidade na vida de homens e mulheres comuns no Século $\mathrm{XX}^{9}$. Somente a partir da revolução sexual ${ }^{10}$ é que começaram a se desenvolver as condiçóes de maior igualdade entre homens e mulheres para a concretização do reconhecimento mútuo entre os amantes, presumida nas interaçóes românticas. "Houve um longo processo de conflitos sociais e políticos para que fossem dadas às mulheres e às minorias sexuais as condiçóes institucionais para o agir livre e autônomo nas relaçóes íntimas" (MATTOS, 2016, p. 429).

Honneth (2015) argumenta que, hoje em dia, as configuraçôes íntimas extrapolam em muito a noção difundida pelo ideal romântico nos Séculos XVIII e XIX, que liga a vida adulta ao casamento, à constituição de uma família nos moldes da família nuclear e à heteronormatividade. Graças às lutas dos movimentos feminista e de minorias sexuais, foi criticado o modelo de família nuclear como única configuração de relaçôes íntimas, dando vazáo para o reconhecimento de novos arranjos conjugais e

9 Eva llouz, em sua pesquisa sobre as relações entre amor e capitalismo nos Estados Unidos, percebe as diferenças entre as classes na intimidade, afirmando que as classes média e alta são muito mais propensas a realizar a utopia romântica (ILLOUZ, 1997, p. 284-285).

10 A revolução sexual nos anos 1960 tem um significado muito mais amplo do que a mera garantia de liberdade sexual para mulheres. A luta feminista e das minorias sexuais permitiu uma notável mudança de costumes, que vem se concretizando no âmbito jurídico e cultural desde então. Para além da liberdade sexual para as mulheres, consumada com o surgimento da pilula anticoncepcional na década de 1960, a revolução sexual concretizou uma série de conquistas na dimensão dos direitos para as mulheres e minorias sexuais - a efetivação da igualdade jurídica entre homens e mulheres, a flexibilização do divórcio, o surgimento dos recasamentos oficiais, "casamentos sem certidão" e a descriminalização da homossexualidade (HONNETH, 2015, p. 262-263). 
familiares, baseados nas afinidades individuais e nas negociações de desejos e necessidades entre os amantes.

Entretanto, as bases normativas desse ideal não mudaram ao longo do tempo. Os amantes nutrem expectativas de serem reconhecidos pela sua singularidade e expressividade, serem amados pelas características que consideram marcantes em suas identidades, melhor dizendo, "nos desejos e interesses que o amado considera significativos para a interpretação de si mesmo" (HONNETH, 2015, p. 265); condição essa para que possam desenvolver uma compreensão positiva de si mesmos.

$\mathrm{Na}$ esfera das relaçóes pessoais, a liberdade se realiza através da percepção dos indivíduos de que eles/elas se completam mutuamente, quer dizer, a vivência livre dos próprios desejos e necessidades é dependente da ajuda e apoio dos outros. Os papéis sociais assumidos pelos sujeitos nas suas interaçóes não são entendidos como uma coação externa à qual são compelidos a se curvarem, mas, antes de tudo, como necessários para a efetivação de sua liberdade. Para Honneth (2015, p. 254), "o outro não é limitação, mas condição da liberdade". O ganho em termos de liberdade individual que as interaçóes amorosas podem propiciar diz respeito ao poder mostrar-se sem reservas e medos para o outro e contar com sua compreensão e apoio. A exigência moral é "de sentir empatia recíproca para com o outro" (HONNETH, 2015, p. 267), sendo os amantes reconhecidos em suas particularidades e até mesmo em suas idiossincrasias pessoais. Na relação sexual, pressupóe-se a entrega livre do corpo para o outro, possibilitando que os amantes façam epifanias, isto é, descubram novos desejos e necessidades por meio dessa interação.

\section{Limitações da reconstrução histórico-normativa de Honneth}

É na esfera das relaçôes pessoais " que Honneth vê significativos progressos morais no que diz respeito à concretização da liberdade atrelada ao

II Sua reconstrução normativa das interações familiares foi criticada por Lois McNay (2015), que afirma que Honneth subestima as persistentes assimetrias de poder nas relações intimas e o aumento das desigualdades sociais em face das politicas neoliberais e de declínio do welfare state. Segundo McNay, as feministas têm mostrado que, apesar de as mulheres estarem maciçamente no mercado de trabalho, elas ainda são as principais responsáveis pelo trabalho doméstico e de cuidados de crianças e idosos. "A ideia da 'mãe de carreira' também é um pouco enganosa já que a maioria das mulheres é empregada em ocupações pouco valorizadas, em tempo parcial" (MCNAY, 2015, p. 177). 
reconhecimento. Ele assinala suas potencialidades, percebendo importantes avanços em termos de aprendizados morais envolvidos no processo de transformação da intimidade que vem se desenvolvendo nas sociedades liberais-democráticas desde a revolução sexual.

Em sua reconstrução das relações íntimas, Honneth recorre reiteradamente às narrativas cinematográficas e literárias por acreditar que elas possam captar, de forma mais acurada, os dramas humanos nas relaçóes amorosas. Inspirado em filósofos ${ }^{12}$ "[...] que tomam os romances como fenomenologicamente a melhor descrição da vida cotidiana” (MARCELO, 2013, p. 215), Honneth adota, em grande medida, essa perspectiva para refletir sobre as relaçóes íntimas na atualidade. Toma a literatura e o cinema como bases empíricas para falar sobre o amor e afirma que essas narrativas, mais do que enaltecer o amor, abordam a crise dos relacionamentos afetivos na contemporaneidade causada pela pouca disponibilidade dos amantes para se vincularem e contraírem obrigaçóes morais nas relações íntimas.

Nesse sentido, Honneth (2015) argumenta que as descrições do cinema e da literatura se coadunam com o diagnóstico feito por Ann Swidler (1980) e Arlie Hochschild (2002), autoras que debateram, cada uma à sua maneira, os efeitos dos imperativos do capitalismo sobre a subjetividade dos indivíduos. A autorrealização na carreira e o progresso profissional passam a estar no centro da noção de bem-viver, colocando-se, cada vez mais, como obstáculos para o estabelecimento de laços afetivos e adoção recíproca de determinadas obrigaçóes de papéis entre os amantes para a concretização de relaçóes íntimas de longo prazo. Isso se agrava, como observou Hochschild, com o esfacelamento das fronteiras entre trabalho e vida pessoal, que obscurece ainda mais a separação entre vínculos pessoais e planos de carreira.

Portanto, quando fala sobre a crise do amor, Honneth aponta os perigos da "formação capitalista da subjetividade". Ele não se atém às ambiguidades envolvidas na democratização das relaçôes de gênero na esfera íntima que resultam também, paradoxalmente, em novos desafios e

12 Sobre a influência da literatura na obra de Honneth, ver Marcelo, 2013, p. 215. 
dificuldades para o reconhecimento mútuo entre os amantes. As interações amorosas baseadas na liberdade de escolha dos amantes, na negociação e cada vez mais nas novas tecnologias - aplicativos móveis para fins de relacionamentos amorosos e sexuais - ensejam novas dinâmicas no mercado afetivo-sexual, regidas por códigos e normas mais fluidos, gerando também novos sofrimentos emocionais. A partir de pesquisas empíricas feitas nos Estados Unidos, na Europa e em Israel, Illouz (2012, p. 130-142) demonstrou como o ideal de autonomia se sobrepóe ao reconhecimento nas relaçôes íntimas na contemporaneidade, diagnosticando que, em nome de sua liberdade e a de seus parceiros, as mulheres recalcam suas demandas por reconhecimento nas interaçóes amorosas. Para Illouz, a vivência da autonomia na esfera privada é mais ambígua e carregada de tensôes para as mulheres do que para os homens.

Talvez por acreditar que as pesquisas sociológicas “[...] sejam frequentemente muito quantitativas e não sensíveis o bastante às nuances da vida cotidiana” (MARCELO, 2013, p. 215) e que seja difícil avaliar a adequação empírica para captar as tendências das relações íntimas (HONNETH, 2015, p. 277), Honneth não incluiu em sua reconstrução histórico-normativa mais estudos empíricos sobre os entraves e impedimentos para o estabelecimento e manutenção de relaçôes amorosas nos dias de hoje.

É verdade que esse tipo de investigação empírica envolve uma permanente reflexão sobre a adequação teórico-metodológica, já que um importante obstáculo é conseguir desenvolver instrumentos para transpor as barreiras morais nas interaçóes entre pesquisadores e pesquisados "[...] que operam no constrangimento da expressão de desejos e afetos que desafiam normas e convençôes morais" (PELÚCIO, 2016, p. 314). Em seus estudos sobre as masculinidades contemporâneas, Pelúcio (2015 e 2016) tem demonstrado a maior eficácia das "pesquisas on-line" em aplicativos de relacionamentos afetivos-sexuais para vencer as barreiras da exposição face a face na realização de pesquisas sobre sexualidade e afeto com homens. A autora conta que, na única vez que encontrou pessoalmente um de seus pesquisados, percebeu uma mudança drástica no seu comportamento. Enquanto nas comunicaçóes virtuais que trocavam, ele era expansivo, falava espontaneamente sobre seus desejos e conquistas nos relacionamentos 
através do aplicativo Ashley Madison, voltado para a promoção de encontros entre pessoas casadas, ao encontrá-la pessoalmente instaurou-se "um mutismo" entre os dois (PELÚCIO, 2015, p. 50).

\section{Achados das pesquisas sobre o amor romântico}

O método adotado foi de entrevistas sucessivas e em profundidade, inspirado no trabalho de Bernard Lahire (2004). Com cada entrevistado ou entrevistada, encontrei-me duas vezes para realizar a entrevista, com exceção de alguns homens ${ }^{13}$ que, por falta de tempo, desinteresse ou até mesmo arrependimento, apenas puderam me encontrar uma única vez. Esse método dá mais subsídios para captar as lacunas nos relatos dos entrevistados e das entrevistadas - as entrevistas são longas (cada encontro leva de $1 \mathrm{~h} 30 \mathrm{~min}$ a $2 \mathrm{~h}$ ), e, em alguns casos, houve um significativo espaço de tempo entre o primeiro e o segundo encontro. Em função da disponibilidade dos(as) entrevistados(as), o intervalo entre as entrevistas variou entre duas semanas e seis meses, o que me possibilitou, ocasionalmente, não só ter acesso a diferentes momentos da vida amorosa deles e delas, como também perceber, de forma mais acurada, as contradiçóes nas falas. Elaborei um roteiro de entrevistas que não foi seguido obrigatoriamente ao pé da letra, abordando várias questóes - definição de amor e romance, práticas românticas, percepçóes gerais sobre os relacionamentos nos dias de hoje, problemas enfrentados por eles e elas em suas relaçóes, percepçóes sobre mudanças e continuidades das relaçóes de gênero na esfera íntima. Realizei ao todo 30 entrevistas com homens e mulheres heterossexuais de classes média e média alta, casados(as), divorciados(as)/separados(as), recasados(as) ou em um relacionamento sério e solteiros(as) entre 25 e 68

13 No total de dezessete homens entrevistados, com seis foi feita apenas uma entrevista. A desistência em fazer a entrevista também foi bem mais frequente entre os homens do que entre as mulheres, levantando questões interessantes sobre a maior abertura delas para falar. Somente duas mulheres desistiram da entrevista; entre os homens foram oito, sendo que três deles fizeram a primeira entrevista e não responderam ao meu e-mail para marcarmos a segunda. Nenhuma das mulheres chegou a fazer a primeira entrevista. Uma delas disse-me que não tinha interesse em falar sobre o tema, mas me ajudou a encontrar outros entrevistados. Três homens comprometeram-se a participar, mas não responderam ao meu e-mail para combinarmos como faríamos a entrevista. Outro, ao falar comigo no telefone, contou-me que, depois de conversar com a sua mulher, achou melhor não dar a entrevista, deixando claro que ela o dissuadiu de realizá-la. E o último deixou explícita a razão da sua recusa, respondendo ao meu e-mail da seguinte maneira: "Patrícia, não me faça parar e refletir sobre relacionamentos nesta altura da vida... Me poupe dessa, please". 
anos. A maioria dos(as) entrevistados(as) está na faixa dos 30 aos 50 anos; 25 entrevistas foram realizadas no Rio de Janeiro (16 homens e 9 mulheres), 2 entrevistas em Juiz de Fora (1 homem e 1 mulher), 2 entrevistas em São João del-Rei (2 mulheres) e 1 entrevista em Brasília (1 mulher). Neste artigo, eu me concentro na análise de 18 entrevistas - 9 homens e 9 mulheres, divorciados(as)/separados(as), solteiros(as), namorando ou em um relacionamento sério. Apenas um entrevistado é casado. Boa parte desses homens e dessas mulheres estava vivendo relaçóes casuais no momento da pesquisa. Três homens estavam namorando e apenas uma das entrevistadas estava envolvida em um relacionamento sério. A escolha das 18 entrevistas se justifica em função da constatação de que os dramas em torno do amor foram mais perceptíveis, em sua complexidade e nuances, nos relatos dos indivíduos que estavam participando do mercado afetivo-sexual.

Já entre os(as) entrevistados(as) casados(as), especialmente os homens, não foi possível identificar tão visivelmente os dilemas e conflitos nas relaçooes íntimas. Em geral, entre os homens casados, houve certa reserva em falar de suas vidas doméstica e conjugal, não havendo muito espaço para expressão de desejos que desafiam as normas morais ou confissóes de seus casos extraconjugais, com exceção de Afonso, como veremos adiante. Constatei que as mulheres se dispuseram mais a falar sobre seus sofrimentos emocionais em torno do amor. Isso pode ter a ver com uma maior abertura feminina para se abrir sobre essa questão. Como percebeu Goldenberg (2010a, p. 13-17), as mulheres se veem como superiores emocionalmente aos homens pela sua maior capacidade de articular emoçóes e sentimentos. Além disso, a cumplicidade de gênero estabelecida entre mim e as entrevistadas também pode explicar a maior disponibilidade delas para falar.

Os cinco homens ${ }^{14}$ que relataram abertamente suas experiências amorosas, frustraçóes de expectativas e dores emocionais têm um perfil parecido. Todos fizeram ou fazem terapia, tendo sido motivados a procurar o tratamento terapêutico, em grande medida, em função de sofrimentos e de

14 Fábio, 40 anos, professor universitário, divorciado, solteiro; Maurício, 44 anos, professor universitário, divorciado, namorando; Ronaldo, 56 anos, gerente de projetos, dois casamentos, solteiro; Ricardo, 44 anos, professor universitário, dois casamentos, solteiro; Júlio, 28 anos, comerciante, divorciado, namorando, mas não se sente comprometido. Todos os nomes dos entrevistados e das entrevistadas são fictícios. Não obtive dados sobre questões raciais. 
conflitos nas suas relaçóes amorosas, o que talvez explique uma maior disposição deles para falar sobre o tema. Dois deles (Fábio, 40 anos, professor universitário, divorciado, solteiro; e Maurício, 44 anos, professor universitário, divorciado, namorando), inclusive, fizeram analogia entre a terapia e a entrevista. Disseram-me que, em alguns momentos da entrevista, falaram como se estivessem em uma sessão de terapia. Três deles tinham um perfil socioeconômico muito semelhante: eram professores universitários, entre 40 e 44 anos, com alto volume de capital cultural, viajados, charmosos e atraentes, segundo os padróes dominantes no mercado afetivo-sexual. Grosso modo, pude perceber que a terapia desempenha um papel relevante para alguns entrevistados e entrevistadas, visto que duas mulheres (Sofia, 50 anos, secretária executiva, separada, solteira; e Ana, 40 anos, jornalista, solteira) fizeram questão de destacar a importância da terapia na identificação de seus autoenganos, suas estratégias e contradições nas relaçóes amorosas. A psicologização do self (ILLOUZ, 2008, 2012) desempenha um papel importante para parte significativa dos sujeitos da pesquisa.

A plausibilidade da utopia romântica descrita a partir da ideia de "alma gêmea", "cara metade”, enfim, de alguém que possa completá-los(as) inteiramente, é questionada pela maioria dos entrevistados(as). Alguns, como Ricardo, 44 anos, professor universitário, dois casamentos, divorciado, solteiro; e Ana, 40 anos, jornalista, solteira, traçam a diferença entre o que é central e o que é ideal no amor. Informam que já tiveram um ideal de amor quando eram mais jovens e que hoje, depois de suas experiências amorosas, reconhecem o quão difícil é viver o amor romântico. Vários homens e mulheres maduros assinalam a diferença entre o amor de juventude e o amor maduro, ressaltando que, quando eram jovens, se apaixonavam facilmente, mas, hoje em dia, fazem cálculos para se envolver em um relacionamento. Boa parte dos(das) jovens entrevistados(as), por sua vez, também náo parece nutrir muitas expectativas românticas. Júlio, 28 anos, comerciante, divorciado, namorando, ainda que não se sinta comprometido, afirma categoricamente: "não existe romance em tempos de relaçóes tinderelas 15 ",

15 Aqui o entrevistado faz referência ao Tinder, que, na época da pesquisa, era o aplicativo mais usado pelos(as) entrevistados(as). Tinder é um aplicativo móvel voltado para relacionamentos afetivos-sexuais. Diferentemente dos primeiros sites de encontro na internet, que usam um questionário definindo os gostos e preferências dos usuários em seu perfil, a apresentação pessoal no Tinder é definida essencialmente pelas fotos postadas e por 
fazendo referência às relações casuais estabelecidas através de aplicativos de relacionamentos. As falas dos entrevistados e das entrevistadas apontam para certa descrença na ideia de que seja possível encontrar alguém que possa compreendê-los totalmente, com quem possam partilhar, sem reservas, sonhos, desejos, dores e frustraçóes.

Ao mesmo tempo em que o ideal romântico motivou o casamento ou envolvimento dos entrevistados e das entrevistadas em relaçóes duradouras, a maioria deles e delas salientou as dificuldades de manter o romance nos relacionamentos "domesticados" (CHAVES, 2006; ABOIM, 2009). A falta de diálogo com seus parceiros ou o desejo em vão de mudar o outro, caracterizando a solidão a dois; as dificuldades de entendimento de necessidades e desejos um do outro e das mudanças do(a) parceiro(a), limitando as promessas de negociação tão características das relaçóes baseadas prioritariamente no afeto e no desejo sexual; ou o reconhecimento precário dos desejos e das necessidades entre os amantes, fruto do arrefecimento da paixão e das exigências e obrigaçôes da vida cotidiana, foram identificados como os principais problemas encontrados nas relaçóes longas que, muitas vezes, levaram ao seu fim.

Esses relatos pareciam confirmar o diagnóstico feito pelos autores "realistas" que salientaram as impossibilidades de realização das promessas românticas (COSTA, 1998, p. 147-159). Mas, apesar desse ceticismo em relação ao amor romântico, que ora aparece de forma cínica e sarcástica, ora de forma melancólica e triste, a busca por autorrealizaçáo no amor ainda move a maioria dos entrevistados e das entrevistadas. Dois entrevistados fizeram questão de destacar isso ao final da entrevista. Fábio, 40 anos, professor universitário, divorciado, solteiro, diz que, da próxima vez que me encontrar, espera "poder relatar experiências mais bem-sucedidas que essa”. Maria, 44 anos, diretora de escola, divorciada, solteira, afirmou que ficou preocupada de ter dado a impressão, na primeira entrevista, de

uma breve descrição do que a pessoa acha importante para caracterizá-la. As fotos servem para decodificar os gostos e estilos de vida (BELELI, 20 I5). Como definiu Illouz (20 I l e 2012), as relações virtuais exigem um alto grau de racionalização dos sujeitos na formulação de seus perfis. Como as interações na internet são padronizadas e uniformes, ganham destaque os sujeitos que conseguem ter uma "originalidade linguística e convencionalidade física", enquadrando-se "nos cânones estabelecidos da beleza e do preparo físico" (ILLOUZ. 20II, p. II9). 
que não acreditava no amor. Ao final da segunda entrevista, Maria reafirma sua crença no amor, apesar das dificuldades de criação de laços mais profundos entre os amantes em uma época em que é "difícil encontrar alguém disposto a se relacionar".

Apesar das reticências e do ceticismo, enxergar e se importar com o outro está na base da regra moral em que deve estar fundamentado o amor para os entrevistados e as entrevistadas. Declaraçóes como "a entrega psíquica e emocional ao outro", "se importar com o outro", "se colocar no lugar do outro" foram frases utilizadas pela maioria dos(as) entrevistados(as) para definir o ideal de amor, ou o que era central no amor. Perceber, cuidar e se preocupar com as necessidades e desejos do outro são pontos cruciais nas relações íntimas para eles e elas. Poder se despir das máscaras sociais (mostrar suas fraquezas e contar com o apoio e estímulo do outro) é um dos elementos que compóem as expectativas normativas do amor para a maioria dos(as) entrevistados(as). Sinceridade, companheirismo, respeito, sintonia, afinidades, admiração e reciprocidade são expressóes frequentemente usadas ao longo das entrevistas para definir o que é central no amor, o que significa perceber o outro e levá-lo em consideraçáo.

É possível detectar as bases normativas do amor tacitamente postas nas relaçóes, ainda que, em geral, os entrevistados e as entrevistadas não façam referências diretas à moralidade nas relações íntimas, até porque as exigências morais costumam ser vistas como opostas à espontaneidade e à autenticidade esperadas nas interaçóes românticas e podem comprometer a autonomia dos amantes (ILLOUZ, 2012, p. 135-136). Como assinalou Honneth (2015, p. 242), essas bases normativas costumam ser mais bem identificadas em momentos de crise, quando são frustradas as expectativas de reconhecimento dos sujeitos nas interaçôes sociais.

Em geral, os homens reconhecem que ainda gozam de melhores condiçóes que as mulheres, localizando as desigualdades de gênero, especialmente no mercado de trabalho e na política. Ao mesmo tempo em que celebram a liberdade sexual feminina, falam sobre as dificuldades dos homens em lidar com essa liberdade conquistada pelas mulheres ${ }^{16}$. A maioria

16 Sobre a ambiguidade da liberdade sexual feminina para os homens, ver também Pelúcio, 2015, p. 318. 
deles não vê uma crise de masculinidade na contemporaneidade e, quando aponta o machismo dos homens, faz isso não falando de si mesmos, mas de conhecidos e amigos. Ronaldo, 56 anos, gerente de projetos, dois casamentos, divorciado, solteiro, expóe seu espanto com a permanência do machismo entre os homens jovens e dá o exemplo de uma conversa que teve com dois deles que afirmaram que não namorariam com as mulheres com quem saem no aplicativo do Tinder - "pô, cara, eu não vou ter uma relação duradoura com aquela mulher que dá para todo mundo". Lucas, 25 anos, estudante universitário, fala sobre o desconforto dos seus amigos que se queixam da liberdade sexual feminina, citando eles: "É muito difícil isso de que a mulher tem liberdade sexual. Você também tem. E é difícil entender que, às vezes, a menina que você ficou com ela ontem, que você transou com ela, hoje está transando com outra pessoa, sem se preocupar com você. Mas, poxa, ela nem me falou nada, nem me ligou”.

Lucas contra-argumenta, dizendo-lhes: "é mais ou menos isso. Mas você já fez isso, faz isso". Ronaldo reconhece sua própria contradição quando relata que ficou muito magoado com sua ex-mulher por ela tê-lo traído e tenta racionalizar sua emoção negativa ao admitir que também teve casos extraconjugais durante o casamento. Quatro homens maduros (Pedro, 44 anos, funcionário público e músico, solteiro; Maurício, 44 anos, professor universitário, divorciado, namorando; João, 50 anos, psicólogo, divorciado, namorando; e Afonso, 68 anos, empresário, casado) fizeram questão de ressaltar seu incômodo com a palavra "traiçáo" sendo usada como sinônimo de relaçóes extraconjugais. De diferentes maneiras, eles verbalizaram que traição é uma palavra muito pesada, pois tem uma conotação de reprovação moral que não deve ser usada para denominar as infidelidades conjugais. "Traiçâo remete a Judas que traiu Jesus", disse-me João. Em contraposição, nenhuma das mulheres demonstrou qualquer constrangimento em usar a expressão traição, seja para dizer que traíram ou foram traídas.

A monogamia é o único pilar da tríade do ideal romântico composta pela ideia de indissolubilidade e heteronormatividade que ainda se mantém para a maioria das mulheres e dos homens entrevistados. Entretanto, os homens são mais ambíguos que as mulheres em relaçáo à monogamia. 
Avento a hipótese de que isso tenha relação com a maior facilidade dos homens em separar sexo de envolvimento emocional, como discutirei adiante. Maurício, 44 anos, professor universitário, divorciado, no espaço de seis meses entre a primeira e a segunda entrevista, relativizou seu estado de apaixonamento descrito na primeira e sua disposição para monogamia. Diz ele: "Se esse formato de casamento que a gente se propóe, se isso dá pra ser assim e as pessoas serem felizes, eu não sei. Eu sigo acreditando, e vou fazer isso. Tô tentando ir para esse caminho de novo, mas eu não tenho certeza não".

Foi possível notar a contradiçáo na fala de Maurício, pois na outra entrevista ele havia contado que, durante seu casamento, teve duas relaçôes extraconjugais com mulheres que conheceu pela internet, arrependendo-se de ter apresentado sua amante para sua ex-mulher, afirmando "Aquilo foi um negócio assim que passou do nivel do respeito". Homens e mulheres reconhecem o quanto é difícil manter a monogamia nas relaçóes mais duradouras, especialmente em tempos de aplicativos de relacionamentos. E alguns admitem pragmaticamente que "o que os olhos não veem, o coração não sente". Grande parte dos(as) entrevistados(as) teve casos extraconjugais. Como constatou Goldenberg (2010b), homens e mulheres são infiéis, não havendo distinção de gênero. No entanto, foi possível notar que alguns homens e algumas mulheres entre 30 e 45 anos tentaram flexibilizar a regra da monogamia tendo "relacionamentos abertos" ${ }^{17 "}$, mas náo encontraram muita satisfação nessas experiências. A proposta de relacionamentos não monogâmicos, na maioria das vezes, partia dos homens. Ricardo, 44 anos, professor universitário, dois casamentos, divorciado, solteiro, conta que fez "lambanças" no seu primeiro casamento ao ser sincero com sua ex-mulher sobre seus desejos sexuais por outras mulheres. Apesar de ela ter sido receptiva e ter proposto que eles fossem a um clube de $s w i n g^{18}$, ele não

17 Quando falam em relacionamentos abertos, nem sempre isso significa que foi algo combinado explicitamente com seu parceiro(a), mas se colocou de forma implícita nas relações. Caroline, 37 anos, professora do ensino médio e doutoranda em sociologia, em um relacionamento sério; e Júlia, 32 anos, secretária, separada, solteira, contam que se sentiram compelidas à traição por perceberem que seus companheiros tinham relações extraconjugais.

18 O swing é uma prática na qual o casal faz sexo com outras pessoas em um mesmo ambiente. Os swingers afirmam-se monogâmicos, uma vez que, apesar de se permitirem ter relações sexuais com outras pessoas, predomina a ideia de que o amor é entre o casal. Sobre novos arranjos conjugais - poliamor, swing $e$ relacionamentos abertos -, ver Pilão e Goldenberg (2012). 
conseguiu se realizar no swing. Buscou ter relações com outras mulheres com anuência de sua esposa, o que acabou colocando em xeque o seu casamento, sem que essas relaçóes extraconjugais tenham sido bem-sucedidas. Afonso, 68 anos, empresário, casado, conta-me consternado que resolveu confessar seus casos extraconjugais para sua mulher, com quem tinha uma ótima relação, depois que ela o "incitou" a isso, perguntando-lhe se nos 40 anos de casados ele nunca a havia traído. Arrepende-se amargamente de ter sido sincero, pois, mesmo dizendo a ela que foram apenas aventuras, ela não o perdoa e vivem há cinco anos a solidão a dois. Acusa-o de tê-la traído durante todo esse tempo, enquanto ele se defende argumentando que náo a traiu, pois nunca a expôs e jamais pensou em terminar o casamento. A maior parte das mulheres disse que a monogamia é importante para elas. Algumas, como Bianca, 34 anos, produtora cultural, solteira; e Caroline, 37 anos, professora do ensino médio e doutoranda em sociologia, dois casamentos, em um relacionamento sério, relataram que, quando eram mais jovens, não se importavam com a monogamia, mas hoje desejam relaçôes monogâmicas.

Entre os homens e as mulheres foi comum a percepção de que as mulheres mudaram muito mais do que eles, que acabam sendo obrigados a mudar a reboque. Em geral, não identificam que exista uma "crise do macho”. Pedro, 44 anos, funcionário público e músico, solteiro, afirma que isso é "um discurso muito midiático". Os homens percebem conquistas no que diz respeito à mudança de costumes, ressaltando que as mulheres estão vivendo a sexualidade de forma livre, como eles. Veem, também, progressos na luta feminista pela igualdade de direitos e na tematização da persistência de uma cultura machista e sexista.

Aliás, a influência do discurso feminista ${ }^{19}$ que se institucionalizou nos últimos tempos no Brasil se evidencia nas entrevistas. Júlio, 28 anos,

19 Não só as Marchas (Marcha das Mulheres, Marcha das Vadias) como também as hashtags feministas (\#ChegaDeFiuFiu, \#MeuPrimeiroAssédio, \#MeuAmigoSecreto, \#EuViviUmRelacionamentoAbusivo, \#MeToo) têm gerado intensas discussões nas redes sociais e na midia. As campanhas feministas que mobilizam um número de mulheres cada vez mais jovens através das hashtags (que são indexadas no aplicativo Twitter e adicionadas ao Facebook. Google elou Instagram) vêm sendo lançadas por internautas e coletivos feministas; sem falar no crescimento do número de coletivos feministas nas universidades e escolas de ensino médio (HEILBORN; O'DWYER; RIBEIRO, 20I8, p. 84). Mesmo que o discurso do movimento feminista não seja univoco, é possivel identificar como motes do empoderamento feminino a luta contra a cultura machista e sexista (denúncia das violências físicas e simbólicas sofridas pelas mulheres) e a desconstrução das identidades fixas de gênero. 
comerciante, divorciado, namorando, conta que, depois da hashtag \#MeuPrimeiroAssédio, percebeu a fragilidade das mulheres frente ao assédio masculino e passou a se policiar para não reproduzir "piadinhas machistas". Ele, inclusive, conversou com umas amigas para tentar escrever uma websérie sobre mulheres fortes no mercado de trabalho na tentativa de empreender a partir do discurso do empoderamento feminino ${ }^{20}$. A força desse discurso é notada quando eles confessam ter receio ou procuram modular suas declaraçóes de modo a náo deixarem margem para serem taxados de machistas ao responderem às perguntas; ou quando dizem que perceberam a naturalização do machismo nas práticas cotidianas; ou, ainda, quando afirmam que, a despeito da cultura machista ser forte entre nós, a crescente emancipação feminina tende a levar a uma mudança de mentalidade e de comportamento em longo prazo. Ricardo, professor universitário, 44 anos, dois casamentos, solteiro, resumiu esse pensamento: "As mulheres estão fazendo o que elas querem. Ai vem a liberdade sexual. Os machistas vão ter cada vez menos mulheres dentro daquele padrãozinho. Ou eles mudam, ou vão se ferrar".

Já Maurício, 44 anos, professor universitário, divorciado, namorando, em um tom bem menos eufórico, comenta que, mesmo sua ex-mulher não sendo feminista, ela usou o discurso feminista em voga para acusá-lo "injustamente" de ter tido um relacionamento abusivo.

Embora os homens tenham assinalado as mudanças nos costumes, foram as mulheres que mais destacaram seu mal-estar com a dinâmica do mercado afetivo-sexual regido por normas mais fluidas em que o "sexo precede o amor" (VICENTE, 2015) e, frequentemente, não resulta em amor. Como afirma Illouz (2012), a revolução sexual possibilitou a separação entre sexo e envolvimento afetivo, criando uma nova economia sexual baseada na sexualidade livre e acumulativa. Ao mesmo tempo em

20 Como demonstram Hamlin e Peters (2018), a noção de empoderamento feminino é polissêmica, sendo usada tanto para denominar as lutas políticas feministas como estando ligada ao consumo, em um sentido individualizante para afirmar valores como independência, sucesso e liberdade, como faz a publicidade. O uso do termo empoderamento pela publicidade produz uma "individualização despolitizante", contrária aos objetivos "de crítica às estruturas de dominação e estratégias coletivas de luta política" do feminismo (HAMLIN; PETERS, 20I8, p. 198). Esses autores fazem uma análise do "feminismo da mercadoria", mostrando como o mercado se apropriou da linguagem emancipatória do feminismo para usá-la para seus próprios fins. 
que a revolução permitiu às mulheres viver sua sexualidade de forma livre, engendrou também novas formas de assimetrias entre os gêneros. $\mathrm{O}$ campo sexual passou a ser fonte de status social para os homens.

[...] Os homens transferiram para o sexo e para a sexualidade o controle que antes exerciam no lar. Desde então, o campo sexual se transformou no âmbito no qual podiam expressar sua autonomia e autoridade. O desapego na sexualidade passou a organizar o tropo mais amplo da autonomia e do controle, ou seja, da masculinidade. (ILLOUZ, 20I2, p. 73).

Em outras palavras, houve uma mudança estrutural na esfera erótica com a institucionalização da liberdade sexual. Além do campo sexual ser uma fonte importante de status social para os homens, como advoga Illouz, eles, antes da revolução sexual, já tinham mais espaço para viver sua sexualidade de forma livre. A dupla moral burguesa permitia o exercício da sexualidade livre exclusivamente para os homens, que podiam ter satisfação sexual fora do casamento com prostitutas ou em relaçóes de concubinato (HONNETH, 2015, p. 260).

Se homens e mulheres entrevistados identificam as dificuldades dos relacionamentos na atualidade, são as mulheres que mais frequentemente relativizam o papel do amor em suas vidas e se contradizem. As mulheres entrevistadas entre 30 e 50 anos enfatizaram as dificuldades de viver o amor em tempos em que predominam as relaçóes casuais, demonstrando, de forma mais contundente e às vezes contraditória, suas ansiedades, angústias e frustraçóes de expectativas amorosas. Pelo fato de que as mulheres que relataram que passaram ou estão há mais tempo sem se envolver em relacionamentos mais significativos, provavelmente, por isso elas precisem recorrer, mais do que os homens, às ponderaçôes contraditórias quanto à importância do amor em suas vidas como táticas de "evitação do sofrimento" (COSTA, 1998, p. 136). Não cabe aqui julgar a eficácia dessas táticas subjetivamente para as mulheres, pois certamente há variaçóes individuais expressivas, mas trazê-las à tona para que possamos discutir as diferenças de gênero e os sofrimentos femininos nas relaçóes íntimas.

No final dos anos 1990 e início dos anos 2000, a máxima “os homens são de Marte, as mulheres são de Vênus ${ }^{2 \mid}$ " como explicação psicológica das

21 O livro com esse título foi publicado pelo psicólogo John Gray, em 1992. 
diferenças de disposiçóes masculina e feminina - os homens mais voltados para o mundo público e para as conquistas nesse mundo e as mulheres mais voltadas para os relacionamentos, amor e família, apontando a inabilidade masculina para os afetos e a superioridade feminina em tudo que se relaciona ao mundo das emoçôes e sentimentos (ILLOUZ, 2012, p. 245) - se popularizou entre nós ${ }^{22}$. Mas, com a propagação do discurso feminista na esfera pública, nos últimos anos, a proposta é criticar esse tipo de explicaçáo que naturaliza a essencialização dos estereótipos de gênero (HEILBORN, 2016; HEILBORN; O'DWYER; RIBEIRO, 2018, p. 89).

Diferentemente do que detectou Goldenberg (2010a, 2010b) em suas pesquisas sobre amor, sexo e intimidade, nas quais as mulheres reclamavam da "falta de homem no mercado", ressaltando o status social dado por ter um homem ao seu lado, que a autora chamou de "capital marido", minhas entrevistadas, em geral, evitam o tom de vitimização. Poucas falaram sobre a "falta de homem", e a maioria salienta sua liberdade e autonomia, de acordo com os imperativos do empoderamento feminino de nossos tempos. Em seus relatos, vez ou outra, fazem um mea culpa também se responsabilizando pelos desencontros amorosos, tendo clareza das disposiçóes necessárias para os relacionamentos afetivo-sexuais, em uma época em que cada vez mais as pessoas se conhecem via aplicativos.

Tanto homens quanto mulheres usuários de aplicativos de relacionamentos como o Tinder ${ }^{23}$, como os náo usuários, queixam-se da

22 A atriz Mônica Martelli ficou conhecida pela peça "Homens são de Marte e é pra lá que eu vou", na qual aborda, com humor, a inabilidade masculina com os sentimentos e emoções, mostrando os contratempos passados pelas mulheres livres e independentes para viver o amor. Essa comédia foi adaptada para o cinema $e$, mais recentemente, virou um seriado no canal GNT. Seguindo os ditames do empoderamento feminino, a atriz atuou em uma websérie no YouTube em comemoração ao dia dos namorados, na qual a ansiedade por estar solteira "dá lugar ao maior amor, o próprio", que pode ser assistida em: https://www.youtube.com/ watch? $=$ IMKSQWyReyg.

23 Das nove mulheres entrevistadas, cinco usam o Tinder. Já entre os homens, somente dois de nove declararam usar o Tinder. Os homens e as mulheres resistentes ao uso deste aplicativo o fazem por várias razões: a) preferência pelas interações face a face e por acreditarem que os aplicativos envolvem a construção de uma persona pública, incitando as pessoas a mentirem; b) por acharem que uso de aplicativos pode denotar certo desespero - como disse Pedro, 44 anos, funcionário público e músico, solteiro, "Afinal, o Rio é cheio de oportunidades de encontros"; c) por perceberem que não são mais tão jovens e não têm muitas chances de sucesso nos aplicativos, cujos principais capitais são a beleza física e a juventude. Não há consenso entre os 
superficialidade dos laços afetivos em nossos dias, da pouca disposição das pessoas para investir nas relaçôes íntimas. Diferentemente do que viu Beleli (2015, p. 100) em suas pesquisas com mulheres que usam aplicativos de relacionamento, nenhuma das entrevistadas externalizou a preocupação de fazer segredo quanto ao uso do Tinder. No entanto, o desconforto com as relaçôes casuais foi mais perceptível entre as mulheres entrevistadas, como veremos a seguir. Somente dois homens ${ }^{24}$ expuseram seu incômodo em relação a elas.

Joana, 44 anos, divorciada, professora de artes, solteira; e Maria, 44 anos, diretora de escola, divorciada, solteira, estranham a forma direta e resumida a sexo dos encontros íntimos na atualidade. Apesar de terem se adaptado à dinâmica do mercado afetivo-sexual, vivendo sua sexualidade de forma livre e acumulativa, declaram esse estranhamento por terem ficado muitos anos casadas. Como atesta Joana: "Os homens já chamam para ir para a cama direto. Normalmente a saida envolve um chope ou alguma bebida num bar e o motel. Esse é um mundo que eu não estava acostumada". Sentem também o peso da competição entre as mulheres e as dificuldades de competir com as mais novas. Afirmam: "Você tem que ser a mais bonita, a mais gostosa”. Maria anuncia que é difícil falar de encontros românticos, pois há anos não tem encontros românticos e teve muitas decepçóes nos últimos anos. Narra que já sofreu com as mentiras e os sumiços dos homens, admitindo que não confia neles. Joana e Maria, cada uma à sua maneira, são as únicas entrevistadas que chamam atençáo para o falso reconhecimento, possivelmente em função de sua menor familiaridade com essas interaçôes: "Então, tem muito essa coisa de a pessoa, num primeiro momento, falar que gosta de mim como pessoa e o negócio encaminhar para o sexo. E, depois do sexo, acabou. A pessoa usa desse artificio para conseguir o sexo, entendeu?" (Joana).

entrevistados e as entrevistadas sobre a finalidade do Tinder. Algumas pessoas identificam, especialmente os homens, que o Tinder tem como finalidade exclusivamente o sexo; outras já acham que as pessoas também buscam estabelecer relacionamentos.

24 Ronaldo, 56 anos, dois casamentos, divorciado, solteiro, por não ser mais jovem, não estar propriamente em forma e perceber que sua força na conquista é a conversa, declarou seu desinteresse e desestímulo pelo uso de aplicativos, que valorizam, sobretudo, a beleza física de seus usuários. Ricardo, 44 anos, professor universitário, dois casamentos, divorciado, solteiro, foi o único entrevistado que falou sobre o seu medo de "broxar" nas relações sexuais casuais. 
Ambas declaram seu desejo de ter um relacionamento, só que não mais nos termos daqueles que viveram envolvendo coabitação. Creem que a experiência de "casais semisseparados" seja mais adequada para elas hoje em dia, isto é, sem compartilhamento de atividades domésticas e compromissos familiares com seus parceiros, estando juntos essencialmente para vivenciarem os momentos de prazer e se apoiarem mutuamente. Maria assume que fica "confusa" quanto à sua vontade de ter um relacionamento, mencionando que tem receio de perder a sua liberdade. Contudo, fica evidente que essa parece ser uma estratégia de defesa, pois, no decorrer das entrevistas, vêm à tona suas angústias e ansiedades quando fala sobre sua relação com Humberto, de 28 anos, que é descrito como "imaturo e galinha”. Mantém uma relação casual com ele, mas admite que gostaria que ele assumisse um relacionamento afetivo com ela.

Sofia, 50 anos, secretária executiva, separada, solteira, também quer viver o amor nos moldes dos casais semisseparados, mas tem encontrado dificuldades para realizar seu desejo. Reitera que tem estabilidade profissional, já teve um casamento convencional, tem uma filha, tendo total autonomia financeira para realizar suas necessidades e anseios "burgueses”, como viagens para o exterior, por exemplo. Questiona-se a respeito de sua necessidade de "etiquetar", quer dizer, definir a relação mesmo que não sonhe mais em ter uma família nuclear. Tem certa relutância em falar do ideal romântico, pois sente que esse ideal a infantiliza, a faz se iludir e não ser realista. No entanto, reconhece que não consegue se libertar dele, pois almeja viver um amor "apaixonado" com base na entrega sexual e afetiva, que lhe dê o reconhecimento pleno de sua singularidade e exclusividade. Queria ter alguém que lutasse por ela e reconhecesse o seu valor, ainda que, como Maria, seja dúbia em relação a isso. Sofia recorre conscientemente a determinadas estratégias para minimizar seu desejo, numa tentativa de racionalizar suas emoçôes. Satisfaz-se por ter autonomia para tocar a própria vida e decidir seu destino, fazendo um esforço para realçar para si mesma o valor de sua liberdade. Confessa que procura diminuir com esse pensamento sua angústia por não estar vivendo o amor da forma como gostaria. Tem 50 anos e sente que decrescem suas possibilidades de viver o amor, assinalando que projeta ter uma vida sexual ativa até os 60 anos. Depois disso, como lhe disse uma amiga: "Cai 
na real; afinal, a menopausa já vai te criar sérios obstáculos para gozar de uma sexualidade plena".

Sofia revela que é apaixonada por Norberto, com quem vive um relacionamento casual, cheio de idas e vindas, ressentindo-se pelo reconhecimento precário de seu papel na vida dele. Apesar de ele elogiá-la frequentemente, valorizando sua inteligência, beleza e sensualidade, não se dispóe a namorá-la. Diz que não está pronto para um relacionamento, ainda que tenha namorado outra pessoa em uma das vezes que estavam separados, o que a magoou muito. Ela nota nitidamente o padrão de comportamento dele, qual seja, quando seus encontros ficam mais frequentes e chegam a envolver saídas para cinema ou restaurantes, ele desaparece por um tempo, fica sem dar notícia. Sofia se constrange por não conseguir resistir a cada volta de Norberto. Constata que está sempre em alerta. Reprime seu desejo de convidá-lo para sair ou até mesmo para o sexo casual e adota a estratégia do desinteresse "como os homens fazem", segundo ela, para não o espantar. Vive o dilema entre o amor possível e o desejável, pois seu ex-marido voltou a procurá-la e, mesmo que não tenha mais tanto desejo sexual por ele, gosta da estabilidade que ele lhe dá e vem mantendo um relacionamento "aberto" e descompromissado com ele. E aí avalia se efetivamente age livremente: "Até que ponto isso tá bom, tá divertido, tá engraçado, tá vantajoso? Até onde eu estou sendo eu mesma, e a partir de quando, estou sendo o que eles querem que eu seja?" (Sofia).

A despeito de terem mostrado claramente seus conflitos internos, Joana e Sofia salientaram que fazem cálculos para se relacionar, realçando também as renúncias que fizeram por perceberem que as histórias não tinham futuro. Joana e Maria, assim como Sofia, também fazem o cálculo dos amores possíveis e dos desejáveis. Mesmo que tenha tido relaçóes casuais com homens casados, Joana afirma que náo quer mais manter esse tipo de relação, demonstrando seu descontentamento em perceber que nos últimos tempos tem atraído, principalmente, homens comprometidos.

Ao contrário de Joana, Maria e Sofia, Júlia, 32 anos, secretária, separada, solteira; e Bárbara, 44 anos, organizadora de eventos, divorciada, solteira, estão "calejadas" no uso do Tinder. Elas se autodefinem "desencanadas e pragmáticas", distinguindo-se das mulheres, inclusive de suas amigas, que 
são descritas como mais emotivas, sonhadoras e idealistas no amor, "[...] tendendo a esperar dos homens o que eles não podem dar" (Bárbara). Relatam terem aprendido a separar sexo de envolvimento e sentem-se à vontade nas relaçóes casuais. Inclusive, Bárbara diz que sua concepção de amor mudou muito: "Talvez tivesse a mesma expectativa que qualquer mulher tem. Porque você vai pra cama com alguém, e é uma entrega incrivel. Você minimamente acha que aquilo vai se desdobrar em alguma coisa. Mas, aprendi a olhar para isso, olhar esse momento de transformaçâo das relaçóes" (Bárbara).

Porém, ao longo das entrevistas, vão aparecendo as ambivalências das duas em relação à sexualidade livre. Bárbara demonstra certo incômodo para falar sobre romance, afirmando, no início da primeira entrevista, que romance não é a cara dela para, depois, admitir que se ressente que, nas relaçóes casuais, os homens separam sexo de envolvimento e carinho. Crê que eles ajam assim com medo de que as mulheres entendam isso como um indício de interesse. Em função do medo do compromisso: "eles não costumam se permitir viver o sexo com envolvimento, nem que seja por uma noite”.

Em alguns momentos da entrevista, Bárbara destaca sua liberdade para criar sentidos no amor e, em outros, a relativiza mencionando que os homens definem, em grande medida, as relaçóes - "escolhendo a mulher para ter aquele compromisso, que só vai se dar se aquela mulher reunir as condiçóes que entrem no planejamento dele". Bárbara - assim como Joana, Maria e Sofia - narra que abdicou de relacionamentos: "Tá sendo difícil encontrar alguém que queira ter uma relaçâo com você. Mas, se a gente começar a olhar para algumas possibilidades, ai eu acho que eu já tive. Mas, eu não posso aceitar uma relação de uma forma que eu já sei que não vai dar certo".

Júlia, por sua vez, na primeira entrevista faz questáo de dizer que não tem ilusôes românticas, descrevendo os desencontros em suas saídas com os homens que conheceu pelo Tinder. Comenta que tem uma relação com um homem casado há mais de um ano e tem plena consciência de que ele não pretende se separar da mulher. Por isso, curte a vida sexual que tem com ele, mas afirma que sai com outros homens. Já na segunda entrevista, em um espaço de três meses, Júlia dá indícios de que está apaixonada pelo seu amante. Argumenta que, desde nosso último encontro, não saiu com outros homens e sabe que é "errado ser fiel a ele", já que seu amante deixou 
claro que não vai mudar a sua vida. Inclusive, Júlia faz questão também de dizer que ela nem quer que ele mude. Mas, essa afirmação parece ser muito mais uma estratégia de defesa do que a sua própria vontade. Isso porque, ao longo da entrevista, ela fala dele de forma elogiosa, afirmando que é com quem tem o melhor sexo que já teve na vida, além de ressaltar as afinidades que eles têm em termos de gostos e estilos de vida. Conta as intimidades deles, as mensagens de "sacanagem" que trocam no celular, os jogos de sedução que ela faz para instigá-lo, o cuidado que ele tem para não postar fotos com a família para não gerar ciúme nela. Mesmo que reafirme diversas vezes que é realista e saiba que seu amante não deixará sua mulher para ficar com ela, é contraditória ao revelar que seus amigos a censuram por manter essa relação, advertindo-a: "Pelo amor de Deus, o cara não vai parar a vida dele por tua causa. E você tá aí parada. Por quêe?".

Enquanto Júlia e Bárbara procuram destacar sua desenvoltura para os encontros casuais, Bianca, 34 anos, produtora cultural, solteira; e Caroline, 37 anos, professora de ensino médio e doutoranda em sociologia, em um relacionamento sério, falam sobre sua mudança de percepção em relação à sexualidade livre e acumulativa, e afirmam seu desejo de ter um relacionamento. Bianca se deu conta das estratégias que usava para esconder de si mesma seu desejo de ter um amor. Tinha uma forma muito pragmática de se relacionar com os homens: "Você tá ai me cantando e tal. Eu sei que você quer me levar pra cama. Se é isso o que você quer, então vamos para a cama. Mas, é o seguinte: é sua obrigaçâo me fazer gozar" (Bianca).

Reconhece que agia de maneira quase caricatural como uma forma de esconder para si mesma sua insegurança nas relaçóes afetivas. Faz um balanço, considera-se bem resolvida profissionalmente, descrevendo-se como "determinada e controladora" no trabalho. Percebe que canalizou toda a sua energia para a vida profissional, pois no trabalho não depende de ninguém e é bem-sucedida, mas admite que é insegura no amor. Faz essa reflexão demonstrando abertamente seu sofrimento emocional pela negação do reconhecimento do envolvimento na relação por parte do seu ex-namorado, Pierre. Conheceram-se no Rio de Janeiro e ficaram mantendo um relacionamento intenso a distância - trocavam inúmeras mensagens diariamente, chegaram a organizar eventos juntos, planejavam férias e viagens - e, quando ela foi visitá-lo na França, foi surpreendida ao ser 
comunicada de que ele estava apaixonado por outra mulher e que ela havia se equivocado quanto às intençóes dele. A sensação de não reconhecimento de sua singularidade e da especialidade da história de amor que viveram é dolorosa para Bianca. Esse sentimento se manifesta quando ela expressa, em alguns momentos das entrevistas, sua incompreensão com a mudança abrupta de emoçôes e comportamento de Pierre. Bianca oscila entre o sentimento de arrependimento, que expressa com lágrimas nos olhos, por náo ter tido coragem de ir embora da casa de Pierre e ter insistido em manter contato com ele durante um tempo "com medo de perder uma coisa que nem tinha", e o de amor, que talvez se censure por ainda senti-lo e procure eufemizar, denominando-o como "gratidão". Relata que Pierre foi o "elefante da floresta", aquele que abriu caminhos lhe permitindo conhecer o sentido do amor.

Já Caroline argumenta, assim como Bianca, que deseja ter uma relação monogâmica, explicitando seus autoenganos em relação à sexualidade livre e acumulativa. Percebeu que teve casos extraconjugais em reação às açôes de seu ex-marido que era infiel quando, na verdade, queria a exclusividade e a atençáo do seu ex. Depois de separada, viveu intensamente sua sexualidade livre e passou, segundo ela, por "situaçôes horrorosas".

Ah, desse vazio, né, dessa ressaca moral. Pô, tudo bem. Dei pro cara lá, transei maneiro. Mas, pô, depois o cara não te trata legal no outro dia, entendeu? Olha pra sua cara, assim, meio te estranhando, meio sai correndo, sabe? Aí depois você encontra o cara na rua, e fala: oi, fulano, tudo bem? E o cara nem fala com você. (Caroline).

Ana, 40 anos, jornalista, solteira; e Ângela, 37 anos, comerciante, divorciada, iniciando um relacionamento na segunda entrevista, também não demonstraram recorrer a qualquer estratégia para declarar que desejam ter um relacionamento. Ângela expóe abertamente sua ansiedade por estar começando uma relação e ter a sensação de que algo pode dar errado, pois essa tem sido a tônica de suas relaçóes desde que ficou solteira. Manifesta, sem rodeios, seu desejo profundo de encontrar alguém. Tanto Ana quanto Ângela reconhecem que os relacionamentos que viveram até então não foram muito satisfatórios, não lhes propiciando efetivamente uma sensação de contentamento nas relaçóes. A lógica das relaçóes casuais é percebida claramente pela maioria dos homens e das mulheres que 
foram entrevistados. Ana sumariza a sensação de sobreoferta da maioria dos(as) entrevistados(as) proporcionada, especialmente, pelo uso de aplicativos para relacionamentos. Essa sensação, ao invés de facilitar a escolha de possíveis parceiros(as), pode colocá-los(as) em um permanente processo de racionalização em termos de uma análise de custo e benefício, ou gerar apatia, conforme assinalou Illouz (2012, p. 95).

Então, você tem milhares de opções. Uma coisa que eu mesma tenho feito é assim: se eu conheci uma pessoa interessante e eu tô encontrando, eu saio, sabe? Porque senão, você perde o foco. Fica ali naquela coisa e nunca evolui, não investe, né? Eu acho que os homens, principalmente, pensam: pra quê que eu vou investir numa só, se tem um cardápio de opções aqui? E aí, então, a pessoa tem que tá muito focada (Ana usou o Tinder durante um ano e pouco, contando-me na última entrevista que havia parado de usar porque estava saindo com um homem interessante que havia conhecido através do aplicativo).

As entrevistadas entre 30 e 50 anos apostam na tática de ir vendo como se desenrolam as interaçóes, investindo na relação quando encontram satisfação nos encontros, mesmo que vivam sua sexualidade de forma acumulativa e não exclusiva. Elas sabem que as fronteiras entre o sexo casual e o compromisso não podem ser estabelecidas previamente e que, nas relaçóes casuais, a norma moral está mais limitada ao respeito ao consentimento dos amantes nas relaçóes sexuais. Têm clareza de que não há muito espaço para demandas em termos de reconhecimento das necessidades e desejos do outro, o que náo impede que elas sintam frustraçóes de expectativas de reconhecimento. Ana, por exemplo, está saindo com Antônio, que conheceu por meio do Tinder. Ela percebe nele interesse e sensibilidade. Como ele é recém-separado, ela disse para Antônio que entende que talvez ele não queira estabelecer um relacionamento agora por estar saindo de um casamento. Avisou-lhe que aceita manter um relacionamento indefinido até o momento que isso não lhe cause dor, já que almeja ter uma relação afetiva. Enquanto Ana declara seu anseio, algumas entrevistadas parecem mais reagir às açóes dos homens do que propriamente agir livremente, de acordo com a sua vontade. Bárbara, 44 anos, organizadora de eventos, divorciada, solteira; e Júlia, 32 anos, secretária, separada, solteira, contaram-me, com altivez, buscando ressaltar sua liberdade de escolha, que é comum bloquearem conversas com homens no WhatsApp quando percebem seus jogos ou falta de interesse, como se estivessem definindo os termos das interaçóes. 
Joana, 44 anos, divorciada, professora de artes, solteira; Caroline, 37 anos, professora de ensino médio e doutoranda em sociologia, dois casamentos, em um relacionamento sério; e Júlia, 32 anos, secretária, separada, solteira, admitiram explicitamente sua reatividade ao falarem que fizeram sexo casual quando, na realidade, queriam a exclusividade. Júlia afirma que traiu o homem que mais amou por não conseguir perdoá-lo por ter mantido um relacionamento com ela e outra pessoa ao mesmo tempo, tendo ficado com ela depois que a outra náo o quis mais. Joana sai com outros homens, mas seu desejo é que Alfredo, com quem está saindo há alguns meses e que não tem interesse em ter um relacionamento, mude de ideia.

A regulação do romance parece ser uma tática masculina, já que alguns entrevistados demonstraram ter a preocupação em não extrapolar os encontros casuais para além do sexo (que até pode envolver um vinho), como quem define as regras da interação. Vários ${ }^{25}$ deles comentam os "mal-entendidos" por que passaram pelas mulheres terem compreendido equivocadamente que havia interesse deles em uma relação. Os jogos de sedução aparecem mais recorrentemente na fala dos homens ${ }^{26}$ do que na das mulheres,

25 Maurício, 44 anos; Ronaldo, 56 anos; Fábio, 40 anos; Júlio, 28 anos, de diferentes formas, falaram sobre esses "mal-entendidos". Se, na primeira entrevista, Ronaldo diz que, por ser gentil e atencioso com as mulheres com as quais teve encontros casuais, ouviu reclamações do tipo: "pô, pensei que a gente tinha outro tipo de relação". E umas mais "escrachadas" falaram: "ninguém trata uma mulher assim se não tiver a fim de ficar com ela"; na segunda entrevista, ele já admite que jogava com as mulheres, seduzindo-as mesmo que não fosse ter nada com elas. Afonso, 68 anos, empresário, casado, conta que se sentia um "supermacho" quando seduzia mulheres, confidenciando que muitas vezes a conquista nem precisava resultar no ato sexual.

26 Pedro, 44 anos, pontua: "O jogo amoroso requer que as coisas tenham certo ritmo, né, uma certa progressividade. Então, se, de cara, você demonstrar tudo e o outro não demonstrou, eu acho que você não tá fazendo o jogo no bom sentido". Marcos, 28 anos, webmaster, diz que está solteiro, mas, na ocasião da realização de nossos dois encontros, atende a ligação da pessoa com quem está saindo, dando-lhe todas as informações sobre o lugar onde está, fazendo referência à entrevista (como se já tivesse falado com ela sobre o assunto), comprometendo-se a retornar sua ligação tão logo chegasse em casa. Enfim, ao contrário do que diz, sua ação demonstra certo grau de comprometimento na relação. Júlio, 28 anos, comerciante, dois casamentos, reclama que sua ex-mulher era muito ciumenta, mas, durante as entrevistas, revela que gostava de mandar presentes, sem se identificar, para mulheres que achava interessantes. Afirma que, por ser um "homem sensivel", é comum as mulheres se confundirem quanto ao seu interesse por elas. Já Fábio conta que, mesmo tendo deixado claro em seus encontros com as mulheres que não estava interessado em relacionamentos, surpreendeu-se com a reação de tristeza e o envolvimento das mulheres com ele, ao dizer a elas que estava em um relacionamento sério e não iria mais encontrá-las. Uma delas começou a persegui-lo, mandando mensagens no WhatsApp para conquistá-lo. Outra the disse: "Nossa, de novo", fazendo referência ao que tem acontecido com ela nas interações com alguns homens que conheceu pelo Tinder. Apesar de ter dito para Fábio que saía com outros homens, estava apenas saindo com ele e tinha esperanças de que pudessem estabelecer um relacionamento. 
dando a entender que eles têm maior domínio das práticas no campo sexual, como afirma Illouz (2012, p. 104). Como pesquisadora, não estou afirmando que as mulheres entrevistadas não façam jogos. Entretanto, as contradiçóes em suas falas parecem indicar que elas atuam de modo mais reativo do que como protagonistas dos jogos amorosos.

Enquanto Joana, Maria, Sofia, Bárbara e Júlia apontam diferenças de gênero em torno do amor, e não propriamente em torno da sexualidade, pois exercem sua sexualidade de forma livre e acumulativa, Ana, Ângela, Bianca e Caroline náo se sentem táo à vontade para fazer generalizaçóes relacionadas às distinçôes de gênero. Ainda que falem espontaneamente sobre diferenças de gênero (através de frases como: "Eu acho que os homens, principalmente, pensam: pra quê eu vou insistir numa só, se tem um cardápio de opçôes aqui"; "As mulheres costumam ser mais emotivas e interessadas no relacionamento"; "Elas têm maior cuidado nas relaçôes, inclusive nas relaçôes casuais"; "Os homens são mais 'cruéis', mais centrados no que querem"), quando são questionadas diretamente sobre essas diferenças entre homens e mulheres no que diz respeito ao amor e à sexualidade, resistem em fazer generalizaçóes. Afirmam que há variaçóes individuais de comportamento no mercado afetivo-sexual, dando exemplos de mulheres que vivem sua sexualidade de forma livre, e de homens sensíveis e românticos. "Eu tenho uma amiga que não quer namorar. Ela só quer trepar mesmo. E ela tem essa coisa de, depois da transa, mandar os caras embora. Ela tem essa parada. Admiro muito. Acho maneiro, sabe?" (Caroline, 37 anos, professora de ensino médio e doutoranda em sociologia, dois casamentos, em um relacionamento sério).

Fábio, 40 anos; Ricardo, 44 anos e Júlio, 28 anos também resistiram a fazer generalizaçôes, destacando as variaçôes individuais de comportamento e as mudanças nas relaçóes de gênero.

Talvez as mulheres idealizem mais no amor; mas, também há homens sensíveis, que têm uma relação idealizada com o amor. Acho que muitos homens têm problema em admitir que têm um ideal romantizado de amor. Eu acho que substantivamente não há diferenças de gênero no amor. (Fábio, 40 anos, professor universitário, divorciado, solteiro).

Outra aceitou ter uma relação casual com ele, mas acabou reconhecendo que não poderia mais vê-lo, pois desejava ter um relacionamento e estava se machucando tendo somente encontros ocasionais. 
Há um tempo atrás, na década de 70, 80, as mulheres queriam se casar, e os homens queriam sexo. Hoje a impressão que dá é que tá o contrário, que os homens querem se casar e as mulheres querem sexo. Então, eu não me arrisco a afirmar qualquer coisa. Eu assisti uma peça em Belo Horizonte que se chamava "Homens querem casar, mulheres querem sexo. (Ricardo, 44 anos, professor universitário, divorciado, dois casamentos, solteiro. Em outras passagens da entrevista, Ricardo afirmou que as mulheres são mais românticas e desejam mais a monogamia, o que ele explicou a partir das diferenças biológicas entre os gêneros).

Em geral, há na fala dos entrevistados e das entrevistadas, até mesmo daqueles(as) que reconheceram abertamente as diferenças de gênero, a percepção da importância e das vantagens de desconstruir os estereótipos de gêneros que a cultura machista constrói e reproduz.

Essa forma de sentir, essas coisas são do machismo, sabe? É um estereótipo de gênero que é socialmente construído de que a mulher deve sempre procurar relações duradouras, consolidadas, e os homens devem ser sempre os comedores, que não querem envolvimento com ninguém. (Caroline, 37 anos, professora de ensino médio, dois casamentos, doutoranda em sociologia, em um relacionamento sério).

Caroline, 37 anos; Pedro, 44 anos; e Ana, 40 anos, acreditam que as geraçôes mais novas estão à frente da deles, conseguindo promover mudanças nas relações de gênero por meio da desconstrução de estereótipos de papéis sociais fixos de masculinidade e feminilidade. Pedro fala do protagonismo das meninas que se declaram bissexuais, sem que isso signifique uma definição preestabelecida da sexualidade, fazendo alusão ao comentário que seu filho fez de que "[...] ninguém namora mais, e quase todas as meninas ficam com outras meninas, como um rito de passagem. Não necessariamente elas vão optar por isso". Caroline, além de destacar a maior abertura dos jovens para se declararem bissexuais e as conquistas dos movimentos de minorias sexuais em promover a diversidade sexual e a crítica à heteronormatividade, fala sobre a "[...] mudança nos usos do corpo. Os homens fazendo uso de peças femininas sem que eles sejam vistos como não homens, sabe?".

\section{Considerações finais}

Os sofrimentos emocionais em função do não reconhecimento, do reconhecimento precário ou falso ficaram mais evidentes nos relatos das mulheres. A indefinição das relaçóes parece constituir, especialmente para 
as mulheres, uma fonte importante dessa sensação de déficit de reconhecimento, expondo algumas ambiguidades que resultaram da crescente individualização e democratização das relações de gênero na intimidade. Se, por um lado, a reconstrução normativa das relaçóes íntimas de Honneth consegue elucidar as regras morais tacitamente postas nas interaçóes amorosas e a importância do amor para uma teoria moral da "boa vida", por outro lado, superestima as potencialidades do reconhecimento nas relaçóes íntimas em face da crescente emancipação das mulheres.

Seja pela necessidade de crítica à cultura machista e/ou pela percepção das variaçóes individuais de comportamento e de mudanças nas relaçóes de gênero que vêm sendo engendradas no campo da sexualidade, verifica-se um obscurecimento das diferenças de gênero em torno do amor e da sexualidade. Ainda que possa significar um relevante ganho as mulheres se permitirem exercer sua sexualidade de forma livre, desconectada da reprodução e baseada no prazer, a sexualidade livre e acumulativa não é um fim em si mesma para a maioria das mulheres entrevistadas, mas um meio para o estabelecimento de uma relação afetiva, uma estratégia que já havia sido identificada por Illouz (2012, p. 105). E aí a percepção de Illouz de que o feminismo não se deu conta, em toda a sua extensão, que a liberdade sexual possa ser também a consagração de um modelo masculino de sexualidade me parece bastante assertiva. O "novo feminismo", ao colocar a desconstrução dos binarismos de gênero como um ideal normativo, acaba também contribuindo, involuntariamente, para eclipsar as diferenças de gênero e tornar imperceptíveis sofrimentos femininos. É inegável que a desestereotipação dos papéis de gênero pode ampliar a gama de liberdade dos atores sociais. No entanto, a situação assume um caráter problemático quando aquilo que era para ser uma escolha se coloca como um "dever ser", estimulando as pessoas a camuflarem de si mesmas os gêneros inscritos em seus corpos e nas estruturas, para usar a expressão de Pierre Bourdieu (1999, p. 122).

Se não é possível falarmos de uma crise do amor nos termos identificados por Honneth, isto é, da erosão da capacidade dos amantes de se vincular, já que grande parte dos entrevistados e das entrevistadas ainda busca se autorrealizar no amor, a análise dos dados de campo me permite apontar o 
caráter ambíguo da liberdade sexual para as mulheres. Foi possível observar que a necessidade socialmente imposta de se adequar ao padrão que desconecta a prática sexual do envolvimento emocional causa angústia, ansiedade ou frustração às mulheres. Tais constataçôes me permitem afirmar que um dos efeitos contraditórios da revolução sexual é que, ao institucionalizar as relaçôes casuais, destituídas de envolvimento emocional, ela exige que as mulheres se adequem a um padrão de conduta no campo sexual que parece contradizer seus anseios, gerando, consequentemente, sofrimento. Obviamente, não posso fazer generalizaçóes a partir de uma pesquisa qualitativa, mas quiçá este artigo possa chamar atenção para a importância dos estudos de gênero no Brasil se voltarem também para os temas do amor e da sexualidade heterossexuais em tempos em que predominam os estudos sobre sexualidades dissidentes.

\section{Referências}

ABOIM, S. Conjugalidades em mudança: percursos e dinâmicas da vida a dois. Lisboa: Imprensa de Ciências Sociais, 2006.

ABOIM, S. Da pluralidade dos afetos. Trajetórias e orientações amorosas nas conjugalidades contemporâneas. RBCS, v. 24, n. 70, p. 107-122, jun. 2009.

ANIMALE BRASIL. Dia dos Namorados - Episódio 1: O Corpo Ideal. 2018. 1 post (1 min.). Postado em 5 jun. 2018. Disponível em: https://www.youtube.com/watch?v=lMKSQWyReyg. Acesso em: 18 ago. 2018.

BECK, U.; BECK-GERNSHEIM, E. O caos totalmente normal do amor. Petrópolis: Vozes, 2017.

BELELI, I. O imperativo das imagens: construção de afinidades nas mídias digitais. Cadernos Pagu, v. 44, p. 91-114, jan./jun. 2015.

BOURDIEU, P. A dominaçáo masculina. Rio de Janeiro: Bertrand Brasil, 1999.

CHAVES, J. Os amores e o ordenamento das práticas amorosas do Brasil da belle époque. Análise Social, v. 180, p. 827-849, 2006.

COSTA, J. F. Sem fraude, nem favor: estudos sobre o amor romântico. Rio de Janeiro: Rocco, 1998.

ELIAS, N. A sociedade dos indivíduos. Rio de Janeiro: Zahar, 1994.

FRASER, N.; HONNETH, A. Redistribution or Recognition? A political-philosophical exchange. London; New York: Verso, 2003. 
FREYENHAGEN, F. Honneth on Social Pathologies: A Critique. Critical Horizons, v. 16, n. 2, p. 131-152, may 2015.

GIDDENS, A. A transformaçáo da intimidade. São Paulo: Ed. Unesp, 1993.

GOLDENBERG, M. Intimidade. Rio de Janeiro: São Paulo: Ed. Record, 2010a.

GOLDENBERG, M. Por que homens e mulheres traem?. Bestbolso: Rio de Janeiro, 2010b.

HAMLIN, C.; PETERS, G. Consumindo como uma garota: subjetivação e empoderamento na publicidade voltada para mulheres. Lua Nova, v. 103, p. 167-202, 2018.

HEILBORN, M. L. Usos e desusos do conceito de gênero. Cult, v. 219, p. 36-39, 2016.

HEILBORN, M. L.; O’DWYER, B.; RIBEIRO, L. Dilemas do feminismo e a possibilidade de radicalização da democracia em meio às diferenças: o caso da Marcha das Vadias no Rio de Janeiro. Civitas, v. 18, n. 1, p. 83-99, jan./abr. 2018.

HOCHSCHILD, A. Keine Zeit. Wenn die Firma zum Zuhäuse wird und zu Hause nur Arbeit wartet. Wiesbaden: VS Verlag, 2002.

HONNETH, A. Luta por reconhecimento. A gramática moral dos conflitos sociais. São Paulo: Ed. 34, 2003.

HONNETH, A. O direito da liberdade. São Paulo: Martins Fontes, 2015.

HONNETH, A. A ideia de socialismo. Tentativa de atualização. Lisboa: Ediçôes 70, 2017.

ILLOUZ, E. Consuming the Romantic Utopia. Love and the Cultural Contradictions of Capitalism. Los Angeles: University of California Press, 1997.

ILLOUZ, E. Saving the Modern Soul. Therapy, Emotions, and the Culture of Self-Help. Berkeley: University of California Press, 2008.

ILLOUZ, E. O amor nos tempos do capitalismo. Rio de Janeiro: Zahar, 2011.

ILLOUZ, E. Why love hurts. Cambridge: Polity Press, 2012.

JÜTTEN, T. Is the Market a Sphere of Social Freedom? Critical Horizons, v. 16, n. 2, p. 187-203, may 2015.

LAHIRE, B. Retratos sociológicos. Disposições e variaçôes individuais. Porto Alegre: Artmed, 2004.

MARCELO, G. Recognition and Critical Theory today: An interview with Axel Honneth. Philosophy and Social Criticism, v. 39, n. 2, p. 209-221, 2013.

MATTOS, P. A mulher moderna numa sociedade desigual. In: SOUZA, J. (Org.). A invisibilidade da desigualdade brasileira. Belo Horizonte: Ed. UFMG, 2006. p. 153-196.

MATTOS, P. A dor e o estigma da puta pobre. In: SOUZA, J.. A ralé brasileira: quem é e como vive. Belo Horizonte: Ed. UFMG, 2009. p. 173-201. 
MATTOS, P. O reconhecimento na esfera do amor: Para uma discussão sobre os paradoxos da transformação da intimidade. Síntese, v. 43, n. 137, p. 421-442, set./dez. 2016.

MCNAY, L. Social Freedom and Progress in the Family: Reflections on Care, Gender and Inequality. Critical Horizons, v. 16, n. 2, p. 170-186, may 2015.

MCNEILL, D. N. Social Freedom as Self-Actualization: Normative Reconstruction as a Theory of Justice. Critical Horizons, v. 16, n. 2, p. 153-169, may 2015.

PELÚCIO, L. Narrativas infiéis: notas metodológicas e afetivas sobre experiências das masculinidades em um site de encontros para pessoas casadas. Cadernos Pagu, v. 44, p. 31-60, jan./jun. 2015.

PELÚCIO, L. Afetos, mercados e masculinidades contemporâneas: notas iniciais de uma pesquisa em aplicativos móveis para relacionamentos afetivos/sexuais. Contemporânea, v. 6, n. 2, p. 309333, jul./dez. 2016.

PILÃO, A. C.; GOLDENBERG, M. Poliamor e monogamia: construindo diferenças e hierarquias. Revista Ártemis, v. 13, p. 62-71, jan./jul. 2012.

ROSENFIELD, C. L.; SOBBOTKA, E. (Org.). Dossiê Justiça e instituiçôes sociais na democracia. Civitas, v. 15, n. 4, p. 567-722, out./dez. 2015.

SCHAUB, J. Misdevelopment, Pathologies, and Normative Revolutions: Normative Reconstrution as Method of Critical Theory. Critical Horizons, v. 16, n. 2, p. 107-130, may 2015.

SILVA, E.; TORRES, R.; BERG, T. A miséria do amor dos pobres. In: SOUZA, J.. A ralé brasileira: quem é e como vive. Belo Horizonte: Ed. UFMG, 2009. p. 143-171.

SIMÓES, J. A.; CARRARA, S. O campo de estudos socioantropológicos sobre diversidade sexual e de gênero no Brasil: um ensaio sobre sujeitos, temas e abordagens. Cadernos Pagu, n. 42, p. 75-98, jan./jun. 2014.

SWIDLER, A. Love and Adulthood in American Culture. In: SMELSER, N. J.; ERIKSON, E. H. (Org.). Themes of Work and Love in Adulthood. Cambridge: Mass, 1980. p. 120-147.

VICENTE, A. "A sexualidade é inevitável: hoje o sexo precede o amor". A socióloga propóe uma surpreendente leitura de Cinquenta tons de Cinza. El País, 30 mar. 2015. Disponível em: https:// brasil.elpais.com/brasil/2015/03/26/cultura/1427384053_822164.html. Acesso em: 18 ago. 2018. 


\section{Challenges of recognition in intimate relationships: a debate with Axel Honneth}

\section{Abstract}

In dialogue with Axel Honneth I analyse the challenges of recognition in intimate relations in the light of qualitative researches about nowadays romantic love conduced with heterosexual men and women from middle and high middle classes. The researches highlighted the ambiguities which resulted from the growing process of individualization and democratization of gender relations in intimacy. Although recognition in intimate relationships is important for men and women, women manifested very explicitly the deficit of recognition in these relationships - either unrecognition, precarious recognition or misrecognition. I emphasize the forms of female emotional suffering originated from the institutionalization of the sexual field, which splitted sex from emotional involvement, spotting the dilemmas and contradictions of female sexual liberty. If, on the one hand, Honneth's normative reconstruction of intimate relations can throw light on the tacit moral rules of love interactions and the importance of love for a moral theory of a "good life", on the other hand it overestimates the potentialities of recognition at the intimate sphere. Additionally, I intend to show the ambivalences of the "new feminism", as well as the limitations of the contemporary studies on gender and sexuality that emphasize "non-normative" sexualities and the deconstruction of gender binarism, which contradictorily contribute to eclipse gender differences on love and sexuality and, then, hinder the perception of female suffering.

Keywords: Love. Recognition. Ambiguity. Sexual Freedom. Feminism.

Recebido em 27/09/2018

Aprovado em 19/11/2018 